\title{
Proposed Reversed Supply Chain as Problem Solver for Case of Returned Beef Products During the Covid- 19 Pandemic
}

\author{
Paduloh Paduloh ${ }^{1, *}$ Taufik Djatna ${ }^{2}$ \\ ${ }^{1}$ Industrial Engineering, Bhayangkara Jakarta Raya University, 12140, Indonesia \\ ${ }^{2}$ Agro-industrial Engineering, IPB University, 16680, Indonesia \\ *Corresponding author. Email: paduloh@dsn.ubharajaya.ac.id
}

\begin{abstract}
Beef is an agro-industrial product that is perishable has a high risk in the pandemic era. The Covid-19 pandemic impacts decreasing consumption of products in various sectors, including beef, with the closure of restaurants and cafes, will affect the accumulation of beef supplies so that the quality decreases and causes multiple problems. This study aims to provide solutions for beef products returned from customers not to become waste and have a detrimental impact on the company. To design a reverse supply chain model research, begins with field observations, designing a reverse supply chain network strategy, and creating a reverse supply chain flow process. Optimizing beef's economic value returned from customers by selling it to customers who use beef quickly and meat-based industries. Products that humans cannot eat can be used as animal or livestock feed. The research found that the reverse supply chain can positively impact company cash flow and indirectly reduce losses due to products being the waste.
\end{abstract}

Keywords: Reverse Supply Chain, Beef, Returned product, Covid-19.

\section{INTRODUCTION}

The Covid-19 Pandemic era affected the economy a lot, where starting in March 2020, the economic activity stopped to reduce the spread of COVID-19. Until now, the economy has not fully recovered. Because in terms of entertainment venues, there are still many that are not open normally, and restaurants and cafes. Based on the coronavirus pandemic, per capita, meat consumption has fallen to the lowest level in the last nine years. Moreover, according to data from the World Food Organization (FAO), meat consumption in 2020 is estimated to fall by 2.8 percent to $42.4 \mathrm{~kg}$ per year per capita compared to last year's $43.6 \mathrm{~kg}$ per year per capita [1]. This condition also has an impact on the accumulation of product stock at retailers and company-owned warehouses. This condition will affect quality degradation because beef's shelf life has an expiration limit of 3 months to 18 months, depending on the type of meat and storage temperature. This condition requires a solution on how to handle products returned from customers not to hurt the company.

The reverse supply chain is an activity to provide value-added to products returned for various reasons [2].
The reverse supply chain is widely discussed and developed with economic motives or environmental sustainability [3]. The stage in Reverse Supply Chain (RSC) is determined by the type of product returns, such as returns from customers, returns of unsold products, returns for repairs, returns to packaging for reuse, expired products, or products that are no longer available. [4]. Retrieval and collection, separation, and inspection of the returned product condition; if the product returned is in terrible condition, it cannot be repaired and cannot be used again at the final inspection stage. Then, the product can be destroyed. If the product is found to be in good condition and still can be reused, the provision of added value or the re-production process can be carried out for the returned product [5].

Previous research about the reverse supply chain has been done [6] discussed the remanufacturing network facility with lagrangian heuristics. [7] discussed a dynamic model to represent reverse logistics to recover product in the end-of-life (EoL) stage, model the dynamics of cost, revenue, and strategic and regulatory decisions. This study to make a strategy for the recovery of electric vehicle batteries. [8] Study the reverse supply chain (RSC) network and design a robust optimization 
model to cope with the ripple effect's uncertainties, a case study from an enterprise disassembling the household appliance in condition. [9] research about the reverse supply chain for a perishable product with four objective functions was considered to maximize profitability and the level of satisfaction with the use of technology, minimize costs and measure environmental impacts. Results show that objective functions are sensitive to demand. [10] Integrated creation and distribution planning in the reverse supply chain using multiobjective mathematical modeling with research on major technology industry problems. The research objective was to minimize total costs, listing costs for creation, maintenance, inventory, and human energy sources. Optimizing customer and supplier satisfaction and maximizing product quality. In this research, the supply chain consists of several suppliers, manufacturers, customers, a revision center for revision of customer items, and a revision center and maintenance for revisions or disposal of products that have passed the warranty period. The results to obtain the maximum value comes from the purpose. In this research, it was discussed about the beef reverse supply chain, which had not been discussed earlier. Like an expensive product, widely consumed but perishable, the reverse supply chain theme for beef is imperative for helping actors in this industry.

Reverse supply chain applications have become a necessity for many industries, with economic reasons to minimize the costs of conducting reverse supply chain activities or transportation costs. Environmental reasons also have a powerful idea, where the pressure to implement green production and green supply chains continues to be voiced to reduce the amount of waste produced. Beef is an agro-industrial product that is easily damaged, so the handlers need special treatment so that the product's shelf life becomes long. It will economically continue to provide benefits and reach a full market. Beef quality is regulated in the Republic of Indonesia laws and has standards based on Indonesian national standards [11] and international standards [12].

The state of this research's art is the reverse supply chain model for beef; this research produces a reverse supply chain model that can be a reference for continuous improvement and the flow of decision-making on returned products based on the quality of the products returned.

\section{METHOD}

This research begins with conducting literature studies and field studies to obtain facts about the problems that exist in the field. Based on these conditions, a strategy is made to apply a reverse supply chain. The reverse supply chain design strategy is made in four stages until we get an outcome from the product's reverse supply chain activity. After that, the reverse supply chain process flow is created as an analysis and decision-making tool based on the product's condition being returned from the customer.

\section{RESULT AND DISCUSSION}

To prevent the product from being returned from becoming more damaged, a back supply chain network is created, and a reverse supply chain flow process is created.

\subsection{Design Network of Reverse Supply Chain}

Regarding the number of products returned from customers due to reduced consumption during the Covid19 pandemic, the first thing that must be done is to prepare a strategy to deal with these returned productsstarting from the location, equipment, and market needs. The technique developed in the reverse supply chain is to maximize the economic value and reduce environmental impacts. Another goal is that the product can be absorbed by the market and has not impacted the environment. Beef products are perishable and can be consumed according to standards so as not to affect health. So in the reverse supply chain, the target that must be set is to provide added value to the product while still paying attention to product quality, product prices, and environmental sustainability. To design a network of beef reverse supply chains, the strategy is made as in Figure 1.

\subsubsection{Phase I: Reverse Supply Chain Strategy}

The strategy used is controlling uncertainty and providing the remanufacturing facilities to maintain product quality. The value-added is maintained, which prevents the meat product from being damaged and becoming waste. Determine the location closest to the customer and most accessible for reverse supply chain activities.

\subsubsection{Phase II. Reverse facility Configuration}

Products returned from customers due to quality and specification reasons must be provided with supporting facilities such as equipment to check product specifications ranging from meat size, color, smell, texture, and bacterial content. The facilities that must be provided are cutting knives, a laboratory, adequate lighting, and proper packaging equipment so that contamination does not occur.

\subsubsection{Phase III. Desirable Value-added}

Products returned from customers for various reasons should be checked by quality. Detailed checks are carried out on returned products on the grounds of faulty 
specifications and decreased product quality. Beef products $100 \%$ meet with Standard National Indonesia (SNI) can be sold directly to customers. Products whose quality has decreased are categorized into categories $\mathrm{A}$, $\mathrm{B}$, and $\mathrm{R}$ according to the following Table 1 .

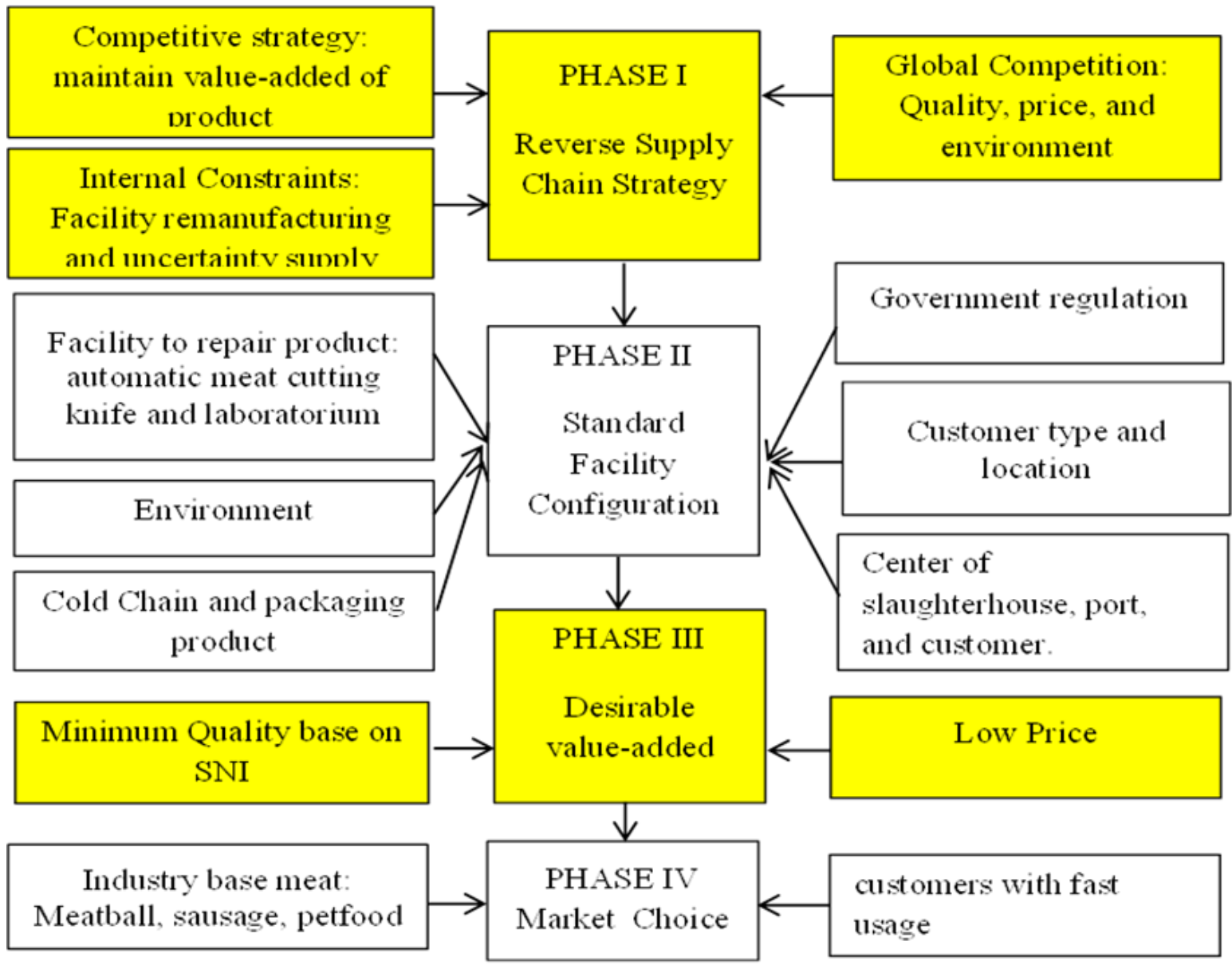

Figure 1 Strategy design network reverse supply chain

Table 1. Category Beef based on Characteristic

\begin{tabular}{clllll}
\hline No & $\begin{array}{l}\text { Beef } \\
\text { Characteristics }\end{array}$ & Good Product & A & B & R \\
\hline 1 & Color & Normal Red & Dull red rather brownish & Dark red-brown & Green / Bubble \\
& & Normal (typical & Normal (typical Beef)/Over & Sour smell & Bad odor \\
2 & Smell & beef) & Aging & Elastic/ rather soft & soft and sticky \\
\hline
\end{tabular}

\subsubsection{Phase IV. Market Choice}

Products with categories A, B, and R are decreasing in quality, so the product must be able to sell as soon as possible so that the product's quality does not more decrease and damage anymore. For products in this category, companies can choose alternatives:

1. Selling products to customers who are immediately using, and the product is not stored.
2. Selling products to become raw materials for a mixture of the food industry, such as sausages, meatballs, or animal feed industries.

Thus the company's losses can be reduced, products can be sold following the value of the remaining products, but can still provide revenue for the company. However, because the number of products in categories $\mathrm{A}, \mathrm{B}$, and $\mathrm{R}$ is uncertain, the availability of this product's stock can only be used as a substitute for raw material or additional raw material. 


\subsection{Flow of Reverse Supply Chain}

To prevent repeated product returns and to make decisions quickly, a reverse supply chain flow chart was created first. Using this flow chart, the company or distributor can control the reasons for product returns and provide preventive measures so that the same incident does not happen, with continuous improvement. After the product is withdrawn and is in the distributor's warehouse, the inspection procedure is carried out. Decision making can be made based on product quality and corrective steps that must be taken so that the product does not accumulate and is immediately handled, does not become increasingly damaged, and can remain economically valuable. In general, the steps taken to accelerate decision making and continuous improvement based on reverse supply chain flow as in Figure 2 in this study can be described as follows:

\subsubsection{Negotiations}

The company can negotiate before withdrawing the product to be returned. Consultations can be done by giving discounts to customers so that they do not need to return products by providing compensation in the form of discounts, taking into account the cost of withdrawal and product risk. The negotiation process must also be carried out when the product is rejected for various reasons, considering that refrigerated trucks' transportation costs require high costs.

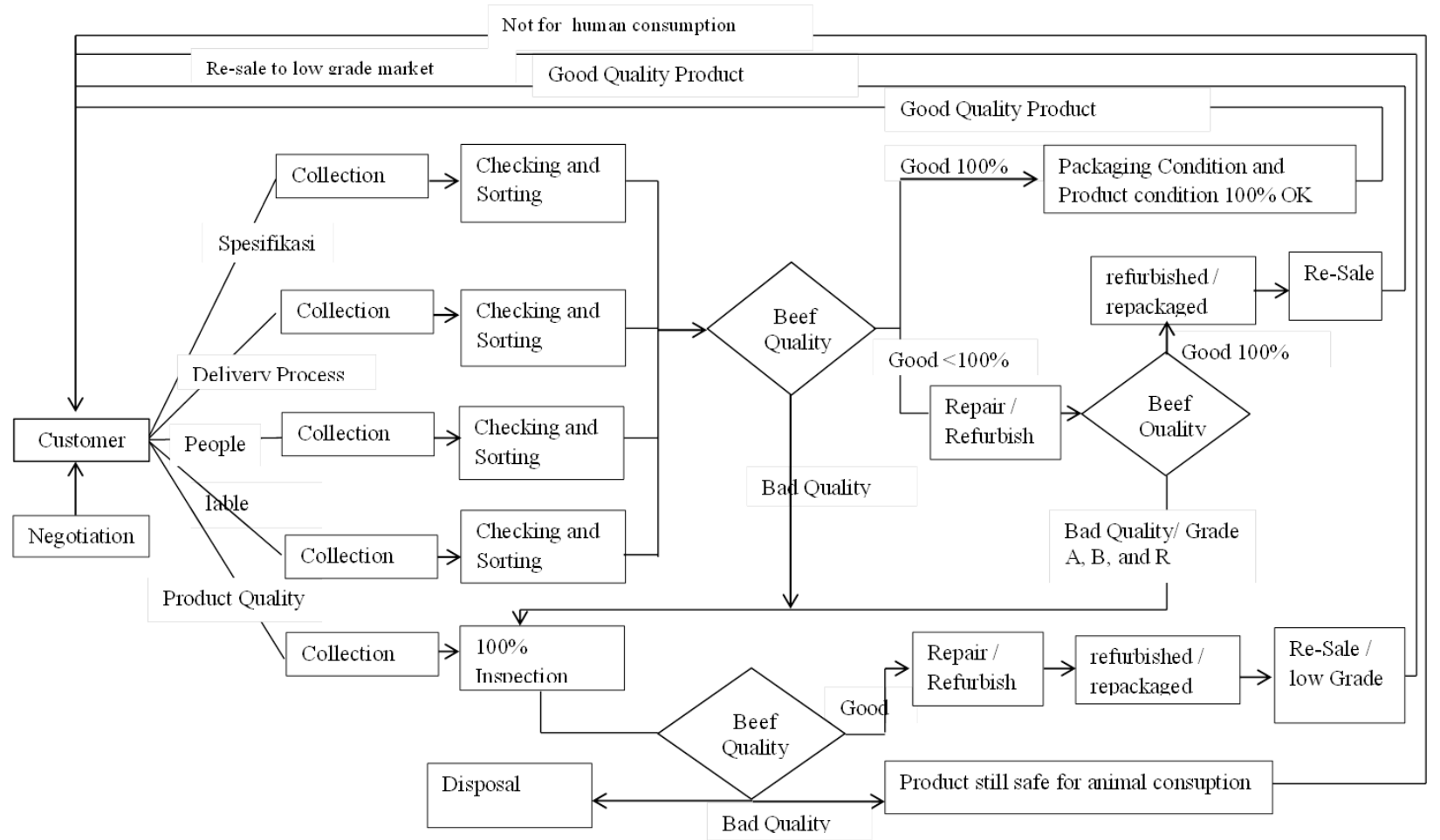

Figure 2 Flow Reverse Supply Chain based on the detailed reason for returning product [13]

\subsubsection{Evaluate the Reason for the Return}

In this COVID-19 pandemic condition, the reasons for returning products must be considered, considering that the returned products are not only related to low product quality, but there are also administrative reasons and poor communication that cause products to be returned from customers to distributors. For that, the company must evaluate contracts with customers and evaluate the performance of the supply chain.

\subsubsection{Product Recall}

The product recall is carried out if negotiations fail. Product recall must consider product quality and product recall facilities so as not to get damaged in transit. The company must also consider the withdrawal costs located far away and transportation costs according to the value of the products being recalled.

\subsubsection{Checking and Shorting}

Control of the quality of products returned from customers is determined at this stage. The quality inspection results will indicate the treatment of the product, and decisions must be made quickly so that losses due to products returned can be reduced.

\subsubsection{Product Quality}

The status and product categories of the products returned are determined at this stage. All products inspected in detail are based on SNI (Indonesian National Standard), which has been translated into company Standards. Products that still meet the standards and have 
no damage both in terms of meat and packaging can be directly sold to different customers. If there is no demand, the product is returned to the warehouse and re-entered into products with CL, CI, and FR categories according to the first category. For products whose quality has declined will be examined in detail and determined to fall into the type A, B, or R. Specifically for products with the category $\mathrm{R}$ directly decided to be destroyed immediately or given to the pet or livestock feed processor.

\section{CONCLUSION}

Reverse Supply Chain Design Network results in products from the reverse supply chains sold to customers who use meat quickly and do not store meat, and products can be sold to meat-based industries. Using reverse supply chain flow, the company can evaluate the causes of the product being returned and speed up decision-making based on the meat's condition from quality control inspection. This research provides the potential for further research to apply reverse supply chain to other industries. Moreover, it can carry out further research by optimizing the cost of reverse supply chain activity. The reverse supply chain model can be used to solve the problem of returning beef products from customers for various reasons.

\section{REFERENCES}

[1] D. A. D. Nasution, E. Erlina, and I. Muda, "The Impact of the COVID-19 Pandemic on the Indonesian Economy," J. Benefits, vol. 5, no. 2, p. $212,2020$.

[2] P. Paduloh, T. Djatna, S. Sukardi, and M. Muslich, "Uncertainty models in reverse supply chain: A review," Int. J. Supply Chain Manag., vol. 9, no. 2, pp. 139-149, 2020.

[3] P. Luitel, K. Lieckens, and N. Vandaele, "Reverse logistics supply chain network design: Models and issues," Int. J. Supply Chain Manag., vol. 3, no. 3, pp. 86-103, 2014.

[4] M. Bouton, K. Govindan, and C. M. T. Rodriguez, "Reducing the extraction of minerals: Reverse logistics in the machinery manufacturing industry sector in Brazil using ISM approach," Resour. Policy, vol. 46, pp. 27-36, 2015.

[5] A. Y. Alqhantani, S. M. Gupta, and K. Nakashima, "One-Dimensional Warranty Policies Analysis for Remanufactured Products in Reverse Supply Chain," Innov. Supply Chain Manag., vol. 11, no. 2, pp. 23-32, 2017.

[6] Z. Lu and N. Bostel, "A facility location model for logistics systems including reverse flows: The case of remanufacturing activities," Comput. Oper. Res., vol. 34, no. 2, pp. 299-323, 2007.

[7] Y. A. Alamerew and D. Brissaud, "Modelling reverse supply chain through system dynamics for realizing the transition towards the circular economy: A case study on electric vehicle batteries," J. Clean. Prod., vol. 254, 2020.

[8] G. Özçelik, Ö. Faruk Yılmaz, and F. Betül Yeni, "Robust optimisation for ripple effect on reverse supply chain: an industrial case study," Int. J. Prod. Res., vol. 7543, 2020.

[9] S. Tavakkoli Moghaddam, M. Javadi, and S. M. Hadji Molana, "A reverse logistics chain mathematical model for a sustainable production system of perishable goods based on demand optimization," J. Ind. Eng. Int., vol. 1, 2018.

[10] S. R. Moghadam, O. Yousefi, M. Kabarsian, and B. Khayabashi, "Integrated production-distribution planning in a reverse supply chain via multiobjective mathematical modeling; case study in a high-tech industry," Prod. Oper. Manag., vol. 9, no. 2, p. 17, 2019.

[11] National standardization Department, "SNI 3932:2008 - 27/5000 Quality of Carcass and Beef," pp. 1-14, 2008.

[12] A. Delgado and D.-W. Sun, Handbook of Frozen Food Processing and packaging. 2011.

[13] P. Paduloh, T. Djatna, M. Muslich, and S. Sukardi, "Impact Of Reverse Supply Chain On Bullwhip Effects In Beef Supply," Ijscm, vol. 9, no. 5, pp. 184-194, 2020 